\title{
FINANCIAL, ABSORPTION AND BUSINESS CYCLES IN SELECTED AFRICAN COUNTRIES
}

\section{Romuald Fernand AWOUTCHA TCHIEUZING $^{1}$ \\ NEBA Cletus YAH $^{2+}$}

\author{
${ }^{1,2}$ Department of Economic Analysis and Policy, Laboratory of Theoretical \\ and Applied Economics, University of Douala, Douala-Cameroon. \\ 'Email:yahneba@yahoo.fr
}

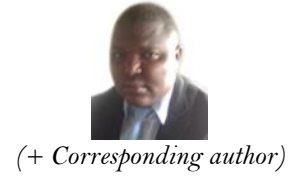

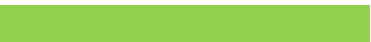

\section{Article History}

Received: 25 January 202 Revised: 2 March 2021 Accepted: 29 March 2021 Published: 15 April 2021

\section{Keywords}

Business cycle

Absorption cycle

Financial cycle African countries.

\begin{abstract}
This study examines the relationship between internal absorption, financial and business cycles in selected African countries. Using Markov's regime change model on data for the period 1960-2018. The data was obtained from the online version of the World Bank's World Development Indicators. The results show that the Keynesian or monetary effects on each phase of the business cycle is different in the various countries. During the phase of economic expansion, the rate of evolution of consumption and gross fixed capital formation accelerate the expansion trend. During the phase of recession, these variables play a stabiliser role by moderating the fall in real GDP. Liquidity ratio and nominal exchange rate affect the behaviour of real GDP in a mixed manner in both the phase of economic expansion and economic recession. These results show that economic policies should focus on household consumption and gross fixed capital formation to regulate the dynamics of the economy.
\end{abstract}

Contribution/ Originality: This study uses a new estimation methodology- Markov's regime change model to ascertain the relationship between financial, absorption and business cycles in a developing country Cameroon. Furthermore, the study contributes to the literature on business cycles by distinguishing deterministic cycles from stochastic cycles using the market hypothesis equilibrium.

\section{INTRODUCTION}

The past few decades have been marked by many phases of decline in economic indicators in most African countries. These recessions were accompanied by financial and budgetary fluctuations. The movement of these variables with time has been the focus of theoretical and empirical debates on the relationship between the real economy and finance. Economic activity brings into play complex relationships which make the actions started by economic agents at a point in time to have a nonlinear effect after a certain time lag. This generates fluctuations in economic activities that need to be forecasted in order to ensure a control of economic growth and its effects, especially as its evolution in time is part of a cyclic dynamics (Lapage, 1981).

In fact, the macro-economy and the financial sector interact closely through the wealth and substitution effects (Cochrane, 2006). Many theoretical and empirical models highlight the role played by credit, particularly to the government, on the evolution of real macroeconomic aggregates during the different phases of the business cycle (Claessens, Kose, \& Terrones, 2011). Most empirical studies explore the pro-cyclical nature of the relationship between financial and macroeconomic variables (Reinhart \& Kenneth, 2009) without explaining their effects on the business cycle. Hobson (1910) puts aside monetary and credit factors to consider only Keyne's propensity to 
consume to explain the phases of the business cycle. In periods of expansion, there is an increase in incomes which leads to a less than proportionate increase in consumption (implying an increase in savings). This saving is then invested, leading to an increase in industrial capacity and production. But since consumption increases less than output, there comes a time when consumption is insufficient and there exists an excess supply of goods. Production therefore drops, leading to a fall in incomes.

According to Tugan-Baranowski (1984) and Spiethoff (1925) overinvestment also means insufficient savings. These authors explain that economic expansion exists when capital is invested quickly because, in one way or the other, it finds an investment. But when several years of prosperity follow each other, the capital reserves decline. Because of a lack of savings to borrow, investments are no longer enough. Investment productivity falls below the level required for equilibrium. As such, total output declines and the ratio of consumer goods to investment goods is relatively high. However, knowledge on the impact of financial and absorption cycles on the business cycle is limited (Claessens et al., 2011). This study seeks to identify stylized facts in African economies which are important for economic policy decision making. In the event of a recession for example, the closing of a company has significant social and economic costs. Households will witness a fall in their purchasing power which is related to both the fall in their income and the toughening of credit conditions. This downward trend signals a transformation of economic, social and even political conditions to the government.

From the foregoing, the following question arises: how does the financial and absorption cycle interact in the phases of the business cycle? In other words, how do consumption, investment and financial cycles affect the business cycle? We address these questions using data on selected African economies for the period 1960 to 2018. Data availability and the size of the economy in its geographical region according to the UN classification guided the selection economies for the study. Furthermore, the study compares the results of the concordance index of Harding and Pagan (2002) with those of the Markov switching model of Hamilton (1989).

The rest of the study is organized as follows: section 2 presents the literature on the theoretical relationship between financial and absorption cycles and the phases of the business cycle. In section 3, the methodology of the study as well as data sources are discussed. Section 4, presents and discuss the estimation results obtained by the switching model. Section 5 is the conclusion.

\section{LITERATURE REVIEW}

When the theory of consumer rationality was formalized between 1860 and 1890 , very few studies were devoted to the question of crises and recovery: only Mill (1848) summarily explained business cycles using psychological causes. Juglar (1862) was one of the first nineteenth century economists to give a detailed explanation of business cycles while highlighting the regularity of the return of crises. Many forms of analyses of the causes and effects of regime change in an economy exist in economic literature. Some studies analyse it according to the time horizon (pre-industrial and post-industrial) and others according to the nature of the origin of the shock (exogenous and endogenous). The exogenous approaches attribute the cause of fluctuations to non-economic factors while the endogenous approaches attribute it to the structure or operation of the economic system itself. It is not always easy to classify a theory in one or the other of these categories (Beitone, Dollo, Cazorla, \& Drai, 2002) and very few studies have been carried out in Africa. In this study, we distinguish deterministic cycles from stochastic cycles using the market hypothesis equilibrium. Unlike the deterministic cycle, a stochastic cycle or quasi-cycle is an oscillatory movement of real GDP and not its deviation from the trend since the factors that generate it are also at the origin of economic growth (French Association of Cliometry, 2010).

\subsection{The Deterministic Approach to Business Cycles}

The deterministic approach to the business cycle supposes that the economy permanently generates forces which accelerate or slow down the level of economic activity. For this sequence to be possible, there should exist: a 
systematic delay in the reactions of economic agents to variations in the economic environment, and imperfect markets since all the economic agents are not rational.

The different monetary mechanisms that affect business cycles are credit (Juglar, 1862), the difference between money interest rate and natural interest rate (Wicksell, 1898) money supply shocks (Hawtrey, 1913) and a combination of a monetary shock and the idea of Wicksell (Hayek, 1929). Hawtrey's theory is important because it shows that shocks on the supply of money generate business cycles, credits playing a central role in the transmission of the shock. Faced with the difficulty of obtaining data on some variables like the interest rate, money supply and the ratio of money supply to GDP are retained for the analysis of financial cycles in this study.

Other business cycle theories are based on a poor distribution of income between saving and consumption, particularly excess savings and insufficient consumption. Malthus (1820) considers that fluctuations in production can be caused by temporary deficits in the demand of goods due to a general excess supply, but these are not regular. It is Hobson (1910) who first explains the effect of consumption on business cycles. This theory, known as the theory of under-consumption is later adopted by Keynes. In periods of expansion, Hobson (1910) believes that incomes increase and thus consumption increases but less than the total increase in income, thus implying an increase in savings. This savings are then invested leading to an increase in industrial capacity and production.

Keynes (1930) explains economic recession using the fact that saving is greater than investment. This creates disequilibrium in the market for consumer goods, obliging the producers of these goods to sell at prices lower than their costs. A deficit in investments or excess of savings is thus the cause of recession. Conversely, economic expansion is explained by the existence of excess investment or savings deficit which generates exceptional profits in the sector of consumer goods and encourages companies to increase production. Crisis occur because during periods of expansion, the demand for means of production increase and because it takes time to build, the persistent shortage in finished goods continues to cause an increase in the demand for consumer goods. This explanation is in line with Hayek (1929).

Tugan-Baranowski (1984) (for long run fluctuations) and Spiethoff (1925) (for short business cycles), explain why prosperity exists when capital is invested quickly. Capital accumulates during a given number of periods, and then is invested, such that the production of capital goods becomes higher than the level of current saving. Investment therefore triggers the different phases of the business cycle. The principle of multiplier-accelerator is thus based on the reaction of investment to disequilibrium in the goods market. In fact, Investment depends on the difference between anticipated demand and production capacity and constitutes an adjustment mechanism that in the long run re-establishes equilibrium in the goods market, thus leading to business cycles (Pierre-Alain, 1994). The association of the multiplier and the accelerator will allow Samuelson (1939) and Hicks (1950), following the first construction of a mathematical model of business cycles by Kalecki (1935) to give an endogenous explanation of business cycles. Household consumption and gross fixed capital formation are therefore retained as indicators of absorption cycles in this study.

The notion of the anticipation of future demand is used by the neo-Keynesians to explain business cycles following neo-classical studies. Neo-Keynesians like Blanchard and Fisher (1989); Mankiw and Romer (1991) explain the propagation of business cycles using market imperfections. Nominal and real imperfections generally generate problems of coordination between the agents, leading to situations of sub-optimal equilibrium. Thus, the economy can at a given time be in equilibrium with low productive activity because of a very low demand, which is also the result of an insufficient level of production that does not generate the income necessary for demand to be higher. Consequently, unlike the neo-classical approach to the business cycle, government intervention plays an important role in the coordination of economic agents and the reversal of the economic situation. However, one of the weaknesses of this approach to business cycles lies in the absence of a unified theoretical framework similar to that proposed by authors of the theory of real business cycles. 


\subsection{The Stochastic Approach to Business Cycles}

These are business cycle theories that consider that the economy is always in a stationary equilibrium and that this equilibrium can be disturbed from time to time by external shocks of real origin. In fact, according to these theories, the economy is prone to random but recurring disturbances which affect both demand and supply. The list of potential disturbances being non-exhaustive, we can think of major or minor events that are favourable or unfavourable which occur in a repeated but non-predictable manner like climate shocks (Jevons (1875) and Moore (1914)), technological innovations (Schumpeter (1939)), productivity shocks (Lucas (1972); Lucas (1973)); (Kydland and Prescott (1982); Long Jr and Plosser (1983)) and exchange rate shocks (Balassa, 1985; Bhagwati, 1988). In this business cycle theory, since the economy is left to itself and adjustments are done through prices, there are delays in the response to shocks in the various sectors of the economy due to a non-coordination of counter-cyclical shocks. This non-coordination could prolong the negative effects. The lifting of institutional rigidities on wages, prices, and interest rates can help in obtaining a faster response to reversal of the cycle. For these authors, the factors that help to maintain the stability of the economic equilibrium are not strong.

For Bhagwati (1988) and Balassa (1985), a real effective exchange that is not over-valued is equivalent to a situation of relative prices with no distortions. This situation makes it possible to fully benefit from the perfect competition which governs the establishment of relative rates. However, today's competition among countries does not correspond to perfect competition. Moreover, Long Jr and Plosser (1983) explain the growth benefits enjoyed by countries with underestimated real effective exchange rates. An underestimated real effective exchange rate contributes in the short and medium run to economic expansion.

Finally, all these economic business cycle theories use economic production, captured by gross domestic product. The evolution of this variable is either due to monetary mechanisms (domestic prices, credit, cash holdings), to real mechanisms (consumption, investment, psychological factors, productivity shocks) or to the international economic situation (the value of the US dollar relative to the national currency, real effective exchange rate). This study therefore proceeds to empirically explain business cycles in selected African countries using real economic variables like consumption and investment; monetary and financial variables like the money supply and the ratio of money supply to GDP; and foreign trade variables such as the exchange rate between the US Dollar and the national currency and the real effective exchange rate.

\section{METHODOLOGY AND DATA OF THE STUDY}

\subsection{Data}

Our sample is made up of a selected number of African countries chosen from UN classified geographical regions. For each geographical region, we retain the two biggest economies with available data. As such, in central Africa we retain Cameroon and the Democratic Republic of Congo (more than $60 \%$ of the wealth of this zone); in Southern Africa, we retain South Africa and Botswana (more than 97\% of the economy of the zone); in West Africa, we retain Côte d'Ivoire and Nigeria (more than $69 \%$ of the wealth of the zone); in East Africa, we retain Kenya and Madagascar (more than $36 \%$ of the wealth of the zone) and in North Africa, we retain Egypt and Algeria (more than $63 \%$ of the wealth of the zone). We therefore have 10 countries that represent the African continent with more than $71 \%$ of the wealth of this continent. For these countries, annual data is obtained from the world development indicators published by the World Bank (World Bank, 2016) for the period 1960 to 2018. The majority of the variables are in constant 2005 US Dollars, except the index of the real effective exchange rate for which the base year is 2010 .

\subsection{Methodology}

Markov Switching Auto-Regressive (MS-AR) models are a class of models which enable the estimation of an auto-regressive (AR) process with a regime change. It is based on the Markov process which formally states that 
the future and the past are conditionally dependent, given the present. The introduction of regime change models to the analysis of time series is done by Hamilton (1988); Hamilton (1989); Hamilton (2003) who inspired many recent contributions in economics. In his 1989 study, Hamilton advances the hypothesis that the evolution of parameters is controlled by an unobservable variable which can be modelled using a Markov chain with $K$ regimes, leading to the name of this type of process: Markov-Switching Models (or $M S(K)$ model).

In economics, the unobservable variable written $S_{t}$ is usually considered to represent the current state of the studied variable. Since $S_{t}$ is unobservable at the time $t$, particularly around the turning points, it can however take a discrete value which depends on its state in the previous period written $S_{t-1}$.

In most applications, the unobservable variable is modelled by a Markov chain with two regimes, i.e. for any time $t$, the variable $S_{t}$ takes value 1 when the variable is in its rising phase and 0 when the variable is in its declining phase. However, some authors (Sichel, 1994) highlight the fact that $M S$ models with only two regimes lack the flexibility to capture with precision the evolution of macroeconomic variables. It is important to note that according to the hypotheses made on the mean (different mean in each regime or not) and on the standard deviation (different variance in each regime or not), the regime change is modelled differently (see Krolzig (1997)).

However, we retain a $M S$ process with 2 regimes because the traditional characterization of the rising/declining phase business cycles originally proposed by Burns and Mitchell (1946) is unanimous. A process $\left(X_{t}\right)$ is described as $M S(2)$ if it verifies the following equations, in the case of an $A R(p)$ process:

$$
\begin{gathered}
X_{t}=a_{0,1}+a_{1,1} X_{t-1}+\ldots \ldots \ldots+a_{p, 1} X_{t-p}+\varepsilon_{t}, \text { when } S_{t}=2 \\
\text { and } \\
X_{t}=a_{0,2}+a_{1,2} X_{t-1}+\ldots \ldots \ldots+a_{p, 2} X_{t-p}+\varepsilon_{t}, \text { when } S_{t}=1
\end{gathered}
$$

Where $\varepsilon_{t}$ is a white noise process with a finite and unknown variance $\sigma^{2}$. We therefore talk of a $M S(2)-A R(p)$ process. Equations 1 and 2 can be rewritten in the following form: $X_{t}=a_{0, s_{t}}+a_{1, s_{t}} X_{t-1}+\ldots \ldots \ldots+a_{p, s_{t}} X_{t-p}+\varepsilon_{t}$

Where $k=0, \ldots \ldots \ldots . . ., p$. We thus have $a_{k, s_{t}}=a_{k, 1}$ when $S_{t}=2$ and $a_{k, s_{t}}=a_{k, 2}$ when $S_{t}=1$.

Moreover, Equation 3 is a complete representation of the $M S(2)-A R(p)$ process and requires the specification of the unobservable variable $S_{t}$ as a Markov chain of first order with 2 regimes. This means the state in which the studied variable is depends only on the preceding regime: for any $t, S_{t}$ depends only on $S_{t-1}$, i.e. for $i=1,2$ and $j=1,2$ :

$$
P\left(S_{t}=j / S_{t-1}=i, S_{t-2}=i, \ldots \ldots \ldots, S_{t-p}=i\right)=P\left(S_{t}=j / S_{t-1}=i\right)=P_{i j}
$$


In Equation 4 the probabilities $P_{i j}$ are the conditional probabilities of transition. We go from a system in a state $i$ at the time $t$ and we want to know the probability distribution at the time $t+1$ and the state $j$. Thus, $P_{i j}$ measures the probability of remaining in the same regime and of passing from one regime to the other.

$$
\begin{array}{ll}
P\left(S_{t}=2 / S_{t-1}=2\right)=P_{22} & P\left(S_{t}=1 / S_{t-1}=1\right)=P_{11} \\
P\left(S_{t}=1 / S_{t-1}=2\right)=P_{21} & P\left(S_{t}=2 / S_{t-1}=1\right)=P_{12}
\end{array}
$$

Where $S_{t}=1$ represents the phase of crisis whereas $S_{t}=2$ represents the growth phase.

$P_{11}$ is the probability that the crisis phase is followed by another (persistence of the recession) and $P_{21}$ indicates that a crisis phase follows a growth phase. $P_{22}$ and $P_{12}$ respectively represent the probabilities that a growth period follows another one (persistence of growth) and that a an expansion phase is preceded by a phase of depression. Thus, we always obtain the following equality:

$$
P_{22}+P_{21}=P_{12}+P_{11}=1
$$

The probabilities $P_{22}, P_{21}, P_{12}$ and $P_{11}$ in Equation 5 above are fixed and are not affected by unspecified information. Moreover, $P_{22}, P_{21}, P_{12}$ et $\left.P_{11} \in\right] 0,1[$ since the Markov chain is irreducible, meaning that there is always a possibility of regime change. There is no absorbing state since there is no probability equal to 1 . The irreducible transition matrix is therefore compatible with the observations: There is never a permanent recession or expansion.

Going from the measures of the persistence of the regime of the series, $P_{22}$ and $P_{11}$, we can obtain an estimate of the average duration of a regime. In fact, if we note $U_{t}^{1}$ the random variable representing the duration or stay of the $M S$ process in mode 1 , given that the initial mode is 1 ; we show that this random variable follows a geometric progression with parameter $\left(1-P_{11}\right)$ as shown in Equation 6 i.e. for all $n>0$, we have:

$$
P\left(U_{t}^{1}=n\right)=P_{11}^{n-1}\left(1-P_{11}\right)
$$

Consequently, the average duration of model 1 is: $E\left(U_{t}^{1}\right)=1 /\left(1-P_{11}\right)$

and the average duration of model 2 is $E\left(U_{t}^{2}\right)=1 /\left(1-P_{22}\right)$

Equation 7 and Equation 8 represent the situation when there is a regime change.

We retain Equation 9 below to examine the effects of the phases of financial and absorption cycles and the international economic situation on the phases of the business cycle:

$$
y_{t}=\mu_{s(t)}+\sum_{i=1}^{k} \varphi_{i, s(t)} y_{t-i}+\sum_{i=1}^{k} \lambda_{i, s(t)} x_{t-i}+\sigma_{s(t)} \varepsilon_{t}
$$


Where:

$y_{t}$ is a measure of the cyclical component of real GDP,

$x_{t}$ is a vector of the cyclical components of the explanatory variables.

The fluctuations of one of the components of $\mathrm{X}$ at time $\mathrm{t}-1$ can cause cyclical movements of $\mathrm{Y}$ in period $\mathrm{t}$, the latter being able to auto-realise itself thereafter.

All the parameters can a priori depend on the value taken by the indicator $s_{t}=\{1,2\}$ of the regimes limited to two possible states:

$\mu_{s(t)}=\alpha_{0}+\alpha_{1} s_{t}$, which describes a possible change in the constant term;

$\varphi_{i_{3} s(t)}=\varphi_{i_{2} 0}+\varphi_{i_{i} 1} s_{t}$, shows a change in the autoregressive component of the explained variable;

$\lambda_{i, s(t)}=\lambda_{i, 0}+\lambda_{i, 1} s_{t}$ Captures the impact of the cyclical component of the lagged explanatory variables on the

cyclical component of the real GDP

$\sigma_{s(t)}=\sigma_{0}+\sigma_{1} s_{t}$, is the conditional heteroskedasticity of the regime

In the following section, uses the results obtained by the MS (2)-AR model to explain the different phases of the business cycles of the selected African countries.

\section{RESULTS AND DISCUSSIONS}

\subsection{Analysis Co-Movements between the Indicators by Country}

The instantaneous and lagged co-movements of each indicators with real gross domestic product is estimated using the methodology proposed by Agénor, McDermott, and Prasad (2000) and Rand and Tarp (2002). The results are presented in Table 1:

Table-1. Co-movements of the components of internal absorption.

\begin{tabular}{l|l|l}
\hline \multirow{2}{*}{ Country } & \multicolumn{3}{c}{ Co-movement with the GDP in constant US Dollars } \\
\cline { 2 - 3 } & $\begin{array}{l}\text { Consumption in constant US } \\
\text { Dollars }\end{array}$ & $\begin{array}{l}\text { Gross fixed capital formation } \\
\text { in constant US Dollars }\end{array}$ \\
\hline Botswana & Procyclical and coinciding & Procyclical and coinciding \\
\hline Côte d'Ivoire & Procyclical and coinciding & Procyclical and coinciding \\
\hline Cameroon & Procyclical and coinciding & Procyclical and coinciding \\
\hline Democratic Republic of Congo & Procyclical and coinciding & Procyclical and coinciding \\
\hline Algeria & Procyclical and coinciding & Procyclical and coinciding \\
\hline Egypt & Procyclical and coinciding & Procyclical and coinciding \\
\hline Kenya & Procyclical and coinciding & Procyclical and coinciding \\
\hline Madagascar & Procyclical and coinciding & Procyclical and coinciding \\
\hline Nigeria & Procyclical and coinciding & Procyclical and coinciding \\
\hline South Africa & Procyclical and coinciding & Procyclical and coinciding \\
\hline
\end{tabular}


Table 1 show that in most the countries, during the whole business cycle, final household consumption is procyclical and coinciding with constant gross domestic product. Final household consumption reacts instantaneously and in the same direction as constant gross domestic product. A variation constant real GDP fully affects final consumption in all these countries and vice versa.

Gross fixed capital formation has the same profile of business activity as final household consumption in these African countries. Using annual data, the gross fixed capital formation by entrepreneurs reacts instantaneously and in the same direction as constant gross domestic product. A variation of the real GDP fully affects the gross formation of fixed assets in all these countries, which in turn affects constant Gross domestic product.

These two indicators of internal absorption are retained for the explanation of the business cycles because they represent more than seventy per cent of the real sector.

Table-2. Co-movements of the components of the financial sector

\begin{tabular}{l|l|l}
\hline \multirow{2}{*}{ Country } & Co-movement with GDP in constant US Dollars \\
\cline { 2 - 3 } & Money supply & Liquidity ratio \\
\hline Botswana & Procyclical and coinciding & Procyclical and coinciding \\
\hline Côte d'Ivoire & Procyclical and coinciding & Procyclical and coinciding \\
\hline Cameroon & Procyclical and coinciding & Procyclical and coinciding \\
\hline Democratic Republic of Congo & Countercyclical and coinciding & Procyclical and advanced two years \\
\hline Algeria & Procyclical and coinciding & Procyclical and coinciding \\
\hline Egypt & Procyclical and lagged one year & Procyclique and lagged two years \\
\hline Kenya & Procyclical and lagged one year & Procyclical and coinciding \\
\hline Madagascar & Procyclical and coinciding & Procyclical and coinciding \\
\hline Nigeria & Procyclical and lagged one year & Procyclical and lagged two years \\
\hline South Africa & Procyclical and coinciding & Procyclical and coinciding \\
\hline
\end{tabular}

From Table 2, we notice that money supply (currency and quasi currency) has a procyclical behaviour but that sometimes coincides (Botswana, Côte d'Ivoire, Cameroon, Algeria, Democratic Republic of Congo, Madagascar and South Africa) and sometimes lagged one year (Nigeria, Kenya and Egypt). The money supply reacts in the same direction and instantaneously for the majority of countries or with one year lag for some relative to gross domestic product, thus respecting the principle of the transactional demand of money. In the same manner, the liquidity ratio evaluates the capacity of the financial institutions to provide liquidity to agents in need of financing (De Gregorio \& Guidotti, 1994).

Table-3. Co-movements of the components foreign trade.

\begin{tabular}{l|l|l}
\hline \multirow{2}{*}{ Country of analysis } & Table-3. Co-movements of the components foreign trade. \\
\cline { 2 - 3 } & $\begin{array}{l}\text { US Dollar- National Currency } \\
\text { exchange rate }\end{array}$ & Real effective exchange rate \\
\hline Botswana & Pro-cyclical and coinciding & Counter-cyclical and lagged two years \\
\hline Côte d'Ivoire & $\begin{array}{l}\text { Pro-cyclical and lagged two } \\
\text { years }\end{array}$ & Counter-cyclical and lagged two years \\
\hline Cameroon & Pro-cyclical and lagged one year & Counter-cyclical and lagged three years \\
\hline Democratic Republic of Congo & Pro-cyclical and forwarded two & Counter-cyclical and lagged one year \\
& years & \\
\hline Algeria & Pro-cyclical and coinciding & Counter-cyclical and coinciding \\
\hline Egypt & Pro-cyclical and coinciding & Counter-cyclical and lagged three years \\
\hline Kenya & Procyclical and coinciding & Counter-cyclical and coinciding \\
\hline Madagascar & Procyclical and coinciding & \\
\hline Nigeria & Procyclical and coinciding & Counter-cyclical and lagged three years \\
\hline South Africa & Procyclical and coinciding & Counter-cyclical and lagged three years \\
\hline
\end{tabular}

In the majority of African economies, this indicator is pro-cyclical and coincides with the evolutions of constant gross domestic product. This supposes that the financial institutions by centralizing liquidity reduce the costs of 
managing the risk of illiquidity and act thanks to the positive externalities on economic growth (Bencivenga \& Smith, 1991). We retain this financial indicator to the detriment of money supply in the explanation of business cycles to avoid the problem of co-linearity between these two variables since they are strongly correlated (Levine, 1997). The results shown in Table 3 imply that real effective exchange rate is counter-cyclical with constant GDP in all the countries. A rise of real effective exchange rate results in a degradation of price competitiveness, leading to a recession. On the other hand, the US dollar - national currency exchange rate evolves in the same direction as constant Gross domestic product all countries. This pro-cyclical relationship between these two indicators is instantaneous or with a delay of one or two years. This indicator is used to capture the international economy instead of real effective exchange rate in the explanation of business cycles to avoid the problem of collinearity between these two variables as they are strongly correlated (Levine, 1997).

To sum up, constant GDP has the same profile with the economic situation as household consumption and gross formation of fixed capital by investors in all the countries. In the same manner, money supply, liquidity ratio of financial institutions and US dollar- national currency exchange rate also have the same profile with constant GDP for most of the countries, unlike real effective exchange rate which is counter-cyclical.

\subsection{Determinants of the Phases of Business Cycles}

Model (9) is estimated by economic regime and by country following the given conditions. We retain as explained variable real GDP growth rate (TPIBR) and as explanatory variables lagged real GDP growth rate (TPIBR (-1)), rate of change of final consumption (TCF), rate of change of gross fixed capital formation (TFBCF), rate of change of liquidity ratio (TM2PIB) and rate of change of nominal exchange rate (TTC).

The components of internal absorption significantly affect economic expansion in the most of the countries in the sample. As shown in Table 4, a $1 \%$ increase in the rate of change of final household consumption leads to an increase in the rate of change of real GDP by 0.55\% in Botswana; 0.17\% in Côte d'Ivoire; 0.17\% in Cameroon; 0.26\% in the DRC; 0.12\% in Algeria; 1.14\% in Egypt; 0.33\% in Kenya and 1\% in South Africa. In countries like Egypt and South Africa, the expansion phase of economic activity is very sensitive to an increase in household consumption.

In the same way, a $1 \%$ increase in the rate of change of gross fixed capital formation leads to an increase in the rate of change of real GDP by $0.19 \%$ in Botswana; 0.23\% in Côte d'Ivoire; 0.36\% in Cameroon; 0.08\% in the DRC; $0.09 \%$ in Algeria; $0.20 \%$ in Madagascar; $0.12 \%$ in Nigeria but to a fall in the sensitivity of 0.05\% in Egypt.

The financial component (liquidity ratio) affects economic expansion in an unclear way (the sign of the coefficient is sometimes positive and sometimes negative). However, in the majority of countries, the liquidity ratio tends to drop, leading to a negative sign of the coefficient: the rate of change of the real GDP is higher than that of money supply. A $1 \%$ fall in the liquidity ratio leads to an increase in the rate of change of real GDP of $0.15 \%$ in Cameroon; 0.04\% in Egypt; 0.44\% in Madagascar and 0.66\% in South Africa. In some countries, the elasticity of the rate of evolution of real GDP relative to the variation in the liquidity ratio is negative, particularly in Côte d'Ivoire, DRC and Algeria.

The nominal exchange rate between the national currency and the US Dollar also affects economic expansion in mixed manner and the status of the exchange rate regime does not bring an explanation to this. Thus, a $1 \%$ increase in the nominal exchange rate leads to a negative and significant fall of $0.19 \%$ in Côte d'Ivoire and $0.08 \%$ in Madagascar, and a positive and significant increase of $0.07 \%$ in Cameroon.

Table 5 shows that the rate of change of household consumption affects the rate of evolution of real GDP during economic recession in a negative and significant manner in Algeria; and in a positive and significant manner in the DRC, Egypt, Kenya, Nigeria and South Africa. Household consumption alleviates the effects of economic recession. 
Table-4. Determinants of the phase of economic expansion.

\begin{tabular}{|c|c|}
\hline Country & Regime1 : Expansion \\
\hline Botswana & 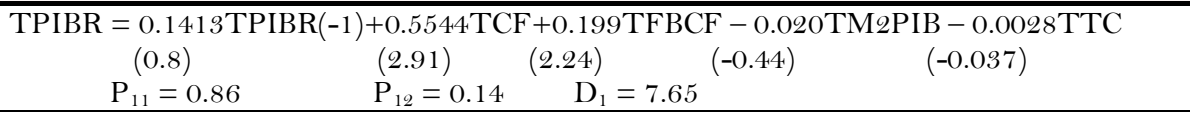 \\
\hline Côte d'Ivoire & $\begin{array}{cccc}\text { TPIBR }=0.6523 \mathrm{TPIBR}(-1)+0.1746 \mathrm{TCF}+0.2330 \mathrm{TFBCF}+0.1896 \mathrm{TM} 2 \mathrm{PIB}-0.197 \mathrm{TTC} \\
\begin{array}{cccc}(77.22) & (54.56) & (31.47) & (43.07)\end{array} \\
\mathrm{P}_{11}=0.19 & \mathrm{P}_{12}=0.81 & \mathrm{D}_{1}=1.24 & \\
\end{array}$ \\
\hline Cameroon & 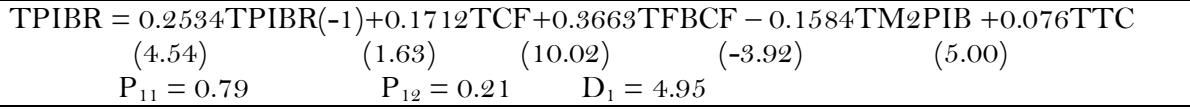 \\
\hline $\begin{array}{l}\text { Democratic } \\
\text { Republic } \\
\text { Congo }\end{array}$ & 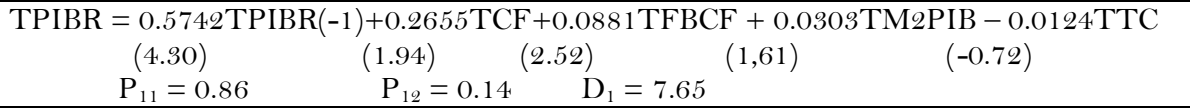 \\
\hline Algeria & 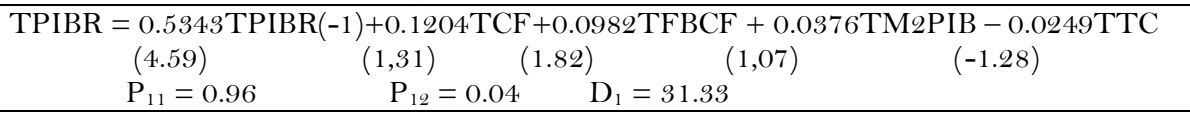 \\
\hline Egypt & 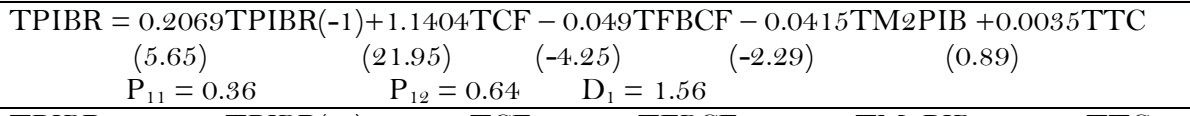 \\
\hline Kenya & 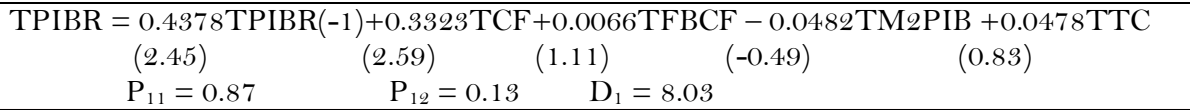 \\
\hline Madagascar & 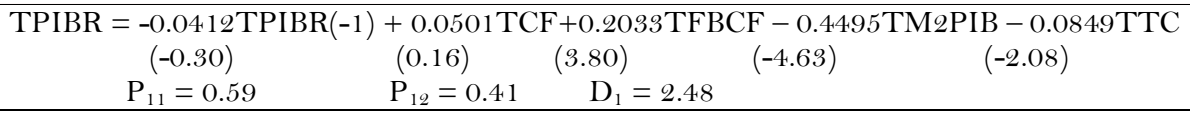 \\
\hline Nigeria & 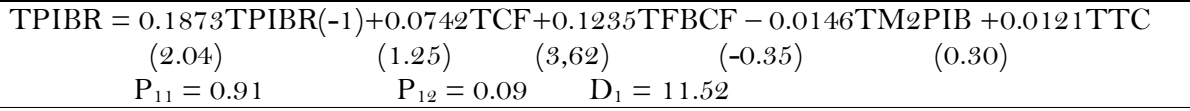 \\
\hline South Africa & $\begin{aligned} \text { TPIBR }= & 0.0457 \mathrm{TPIBR}(-1)+1.0003 \mathrm{TCF}+0.0376 \mathrm{TFBCF}-0.6677 \mathrm{TM} 2 \mathrm{PIB}-0.1180 \mathrm{TTC} \\
& (0.16) \quad(3.00) \quad(0.57) \quad(-2.62) \\
\mathrm{P}_{11}=0.94 & \mathrm{P}_{12}=0.06 \quad \mathrm{D}_{1}=17.03\end{aligned}$ \\
\hline
\end{tabular}

Table-5. Determinants of the phase of economic recession.

\begin{tabular}{|c|c|}
\hline Pays & Régime2 : Recession \\
\hline Botswana & 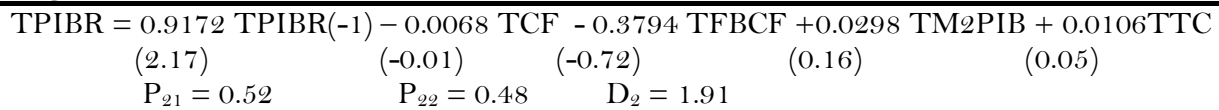 \\
\hline Côte d'Ivoire & $\begin{array}{c}\text { TPIBR }=0.3379 \mathrm{TPIBR}(-1)-0.0809 \mathrm{TCF}+0.3197 \mathrm{TFBCF}-0.0691 \mathrm{TM} 2 \mathrm{PIB}-0.4987 \mathrm{TTC} \\
\begin{array}{cccc}(2,61) & (-0.45) & (2.14) & (-0.29) \\
\mathrm{P}_{21}=0.18 & \mathrm{P}_{22}=0.82 & \mathrm{D}_{2}=5.39 & (-4.33)\end{array}\end{array}$ \\
\hline Cameroon & 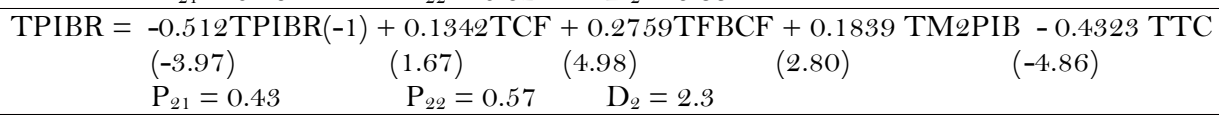 \\
\hline $\begin{array}{l}\text { Democratic } \\
\text { Republic } \\
\text { Congo }\end{array}$ & 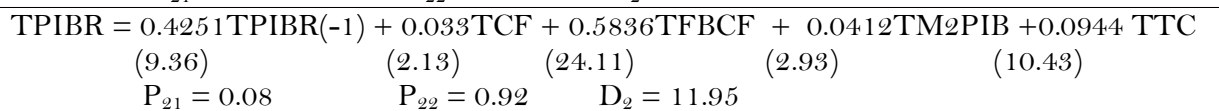 \\
\hline Algeria & $\begin{array}{cccc}\text { TPIBR }=-0.7841 \mathrm{TPIBR}(-1) & -0.5191 \mathrm{TCF}+1.542 \mathrm{TFBCF}+0.3506 \mathrm{TM} 2 \mathrm{PIB}+0.1463 \mathrm{TTC} \\
(-7.12) & (-2.73) & (7.22) & (1.49) \\
\mathrm{P}_{21}=0.36 & \mathrm{P}_{22}=0.64 & \mathrm{D}_{2}=2.77 & (0.60)\end{array}$ \\
\hline Egypt & 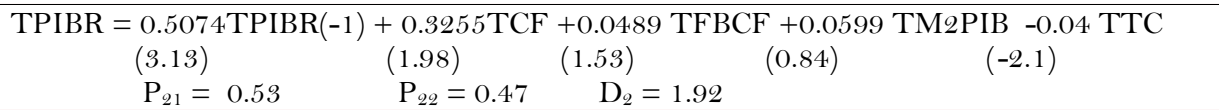 \\
\hline Kenya & $\begin{array}{c}\text { TPIBR }=0.3476 \mathrm{TPIBR}(-1)+0.4913 \mathrm{TCF}-0.0288 \mathrm{TFBCF}-0.1308 \mathrm{TM} 2 \mathrm{PIB}+0.0103 \mathrm{TTC} \\
\begin{array}{cccc}(9.48) & (19,25) & (-29.41) & (-10.7) \\
\mathrm{P}_{21}=0.51 & \mathrm{P}_{22}=0.49 \quad \mathrm{D}_{2}=1.92 & \end{array}\end{array}$ \\
\hline Madagascar & 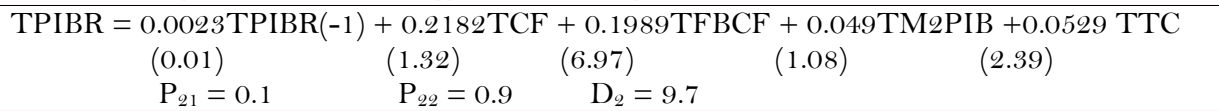 \\
\hline Nigeria & 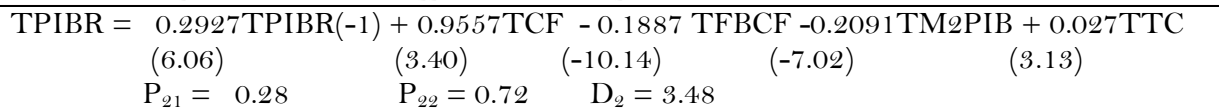 \\
\hline South Africa & $\begin{array}{cccc}\text { TPIBR }= & -0.1348 \mathrm{TPIBR}(-1)+0.7068 \mathrm{TCF}+0.0987 \mathrm{TFBCF}+0.0058 \mathrm{TM} 2 \mathrm{PIB}+0.0193 \mathrm{TTC} \\
(-1.33) & (8.91) & (2.71) & (0.12) \\
\mathrm{P}_{21}=0.02 & \mathrm{P}_{22}=0.98 & \mathrm{D}_{2}=5.91 & \end{array}$ \\
\hline
\end{tabular}


In the same manner, the rate of change of gross fixed capital formation affects the rate of evolution of real GDP during economic recession negatively in Kenya and Nigeria; and positively in Côte d'Ivoire, Cameroon, the DRC, Algeria, Madagascar and South Africa. Gross fixed capital formation alleviates economic recession but less than household consumption. Liquidity ratio has a positive and significant relationship (since money supply falls slowly than real GDP) in countries like Cameroon and the DRC. It has a negative and significant relationship (since money supply falls faster than real GDP) in Nigeria. Nominal exchange rate has a positive and significant relationship with real GDP in countries like DRC, Kenya, Madagascar, and Nigeria. It has a negative and significant effect in countries like Côte d'Ivoire and Cameroon.

\section{CONCLUSION}

This study shows the possible contribution of absorption and financial cycles to the explanation of the phases of business cycles in Africa. We find that behaviours are not symmetrical from one phase to another. During the phase of economic expansion, the rate of evolution of consumption and gross fixed capital formation accelerate the expansion trend. During the phase of recession, these variables play a stabiliser role by moderating the fall in real GDP. Liquidity ratio and nominal exchange rate affect the behaviour of real GDP in a mixed manner in both the phase of economic expansion and economic recession. These results show that economic policies should focus on household consumption and gross fixed capital formation to regulate the dynamics of the economy.

Funding: This study received no specific financial support.

Competing Interests: The authors declare that they have no competing interests.

Acknowledgement: Both authors contributed equally to the conception and design of the study.

\section{REFERENCES}

Agénor, P.-R., McDermott, C. J., \& Prasad, E. S. (2000). Macroeconomic fluctuations in developing countries: Some stylized facts. The World Bank Economic Review, 14(2), 251-285.Available at: https://doi.org/10.1093/wber/14.2.251.

Balassa, B. (1985). Exports, policy choices, and economic growth in developing countries after the 1973 oil shock. Journal of Development Economics, $18(1), 23-35$.

Beitone, A., Dollo, C., Cazorla, A., \& Drai, A.-M. (2002). Dictionary of economics. Paris: Armand Colin.

Bencivenga, V. R., \& Smith, B. D. (1991). Financial intermediation and endogenous growth. The Review of Economic Studies, 58(2), 195-209.Available at: https://doi.org/10.2307/2297964.

Bhagwati, J. N. (1988). Export-promoting trade strategy: Issues and evidence. The World Bank Research Observer, 3(1), 2757.Available at: https://doi.org/10.1093/wbro/3.1.27.

Blanchard, \& Fisher. (1989). Lectures on macroeconomics. MIT Press: Cambridge.

Burns, A. F., \& Mitchell, W. C. (1946). Measuring business cycles. New York: NBER.

Claessens, S., Kose, M. A., \& Terrones, M. E. (2011). Financial cycles: What? How? When? Paper presented at the International Seminar on Macroeconomics. Chicago, IL: University of Chicago Press.

Cochrane, J. H. (2006). Financial markets and the real economics. Cheltenham, UK: Edward Elgar.

De Gregorio, J., \& Guidotti, P. E. (1994). Financial development and economic growth. World Development, $\mathrm{N}^{\circ} 23$.

French Association of Cliometry. (2010). The economic cycle. A Working Parpers Synthesis $n^{\circ} 4$.

Hamilton, J. D. (1988). A neoclassical model of unemployment and the business cycle. Journal of Political Economy, 96(3), 593617.Available at: https://doi.org/10.1086/261553.

Hamilton, J. D. (1989). A new approach to the economic analysis of non-stationary times series and the business cycle. Econometrica, 57(2), 357-384.Available at: https://doi.org/10.2307/1912559.

Hamilton, J. D. (2003). Comment on “A comparison of two business cycle dating methods". Journal of Economic Dynamics and Control, 27(9), 1691-1693.Available at: https://doi.org/10.1016/s0165-1889(02)00077-5. 
Harding, D., \& Pagan, A. (2002). Dissecting the cycle: A methodological investigation. Journal of Monetary Economics, 49(2), 365381.Available at: https://doi.org/10.1016/s0304-3932(01)00108-8.

Hawtrey, R. (1913). Good and bad trade. London: Constable.

Hayek, F. (1929). Monetary theory and the trade cycle. London: Originally Published in German.

Hicks, J.-R. (1950). A contribution to the theory of the trade cycle. Oxford University Press.

Hobson, J. A. (1910). The industrial system. New York: Charles Scribner's Sons.

Jevons, S. (1875). Influence of the Sun-Spot period on the price of corn. Nature, 15(1), 1-25.

Juglar, C. (1862). Trade crises and their periodic returns in France, England and the United States. Alternatives Economiques, $\mathrm{n}^{\circ} 178$.

Kalecki, M. (1935). A macrodynamic theory of business cycles. Econometrica, Journal of the Econometric Society, 3, $327-344$.

Keynes, J. M. (1930). A treatise on money. New-York: Harcourt Brace: Cambridge University Press.

Krolzig, H. (1997). Econometric modeling of Markov-switching vector autoregressions using MSVAR for OX. Oxford: Institute of Economics and Statistics.

Kydland, F. E., \& Prescott, E. C. (1982). Time to build and aggregate fluctuations. Econometrica: Journal of the Econometric Society, $50,1345-1370$.

Lapage, J. M. (1981). Growth and cycles. Paris: Synonyme-Sor.

Levine, R. (1997). Financial development and economic growth: Views and agenda. Journal of Economic Literature, 35(2), 688-726.

Long Jr, J. B., \& Plosser, C. I. (1983). Real business cycles. Journal of Political Economy, 91(1), 39-69.

Lucas, R. E. (1973). Some international evidence on output-inflation tradeoffs. The American Economic Review, 63(3), 326-334.

Lucas, R. (1972). Expectations and the neutrality of money. Journal of Economic Theory, 4(2), 103-124.

Malthus, R. (1820). Principles of political economy. Paris: Calmann-Lévy.

Mankiw, N., \& Romer, D. (1991). New Keynesian economics. Cambridge: MIT Press.

Mill, S. (1848). The principles of political economy: With some of their applications to social philosophy. London.

Moore, H. (1914). Economic cycles: Their law and cause. New-York: Macmillan.

Pierre-Alain, M. (1994). Growth and cycles. Paris: Economica.

Rand, J., \& Tarp, F. (2002). Business Cycles in developing countries: Are they different? World Development, $\mathrm{N}^{\circ} 30$.

Reinhart, C. M., \& Kenneth, S. R. (2009). This time is different: Eight centuries of financial folly. USA: Princeton University Press.

Samuelson, P. H. (1939). Interactions between the multiplier analysis and the principle of acceleration. The Review of Economics and Statistics, 21(2), 75-78.Available at: https://doi.org/10.2307/1927758.

Schumpeter, J. A. (1939). Business cycles: A theoretical, historical and statistical analysis of the capitalist process, 2VLS. New-York: McGraw-Hill.

Sichel, D. E. (1994). Inventories and the three phases of the business cycle. Journal of Business \& Economic Statistics, 12(3), 269277.Available at: https://doi.org/10.1080/07350015.1994.10524542.

Spiethoff, A. (1925). Krisen. Concise Dictionary of Political Science, 6, 8-91.

Tugan-Baranowski, M. I. (1984). Industrial crises in contempory England, their causes and influences on national life (2nd Russian ed.). St Petersburg.

Wicksell, K. (1898). Interest and prices: A study of the causes regulating the value of the money, Royal Economic Society.

World Bank. (2016). World development indicators-online version. Retrieved from: http://wdi.worldbank.org. [Accessed 22 April, 2016]. 